\title{
Håndtering af hellige ting - i museer
}

\author{
RolF GILBERG*
}

Title: Handling of sacred objects - in museums.

Abstract: The paper focus on handling of scared objects in a museum. Even when the museum staff do not belong to the religion in question, one should handle the objects with respect and understanding, and let these qualities be part of the visitors experience.

Key words: Sacred objects, respect, Lame Deer, medicine bundle, Mongol shaman, Buddha figur, North American indians, totem pool.

I 1997 udgav Nordisk Museologi artiklen: "Hvem ejer museumsgenstandene?" (Gilberg 1997), som handler om hvem, der bestemmer over, hvordan museumsgenstande skal forstås og forklares. Gennem en række eksempler afdækkes problemerne. Kort fortalt handler det om, hvem der har retten til kulturen, eller er der ingen, der har det, eller måske os alle eller kun det folk, som eksemplet handler om. Denne artikel er en fortsættelse. $\mathrm{Nu}$ drejer det som om at ville vise andre folks kultur respekt. De 2 artikler overlapper med eksemplet om den indianske medicinmand Lame Deer og hans afhelligficering af en indiansk medicinpakke. Denne gang fokuserer jeg på, hvordan museer bør tage vare på religiøse genstande i deres samlinger uanset, om tingene er udstillede eller opholder sig på magasin.

\section{HVAD ER EN HELLIG TING?}

En hellig ting er en genstand som direkte eller indirekte indgår i udøvelsen (kulten) af en religion. Hellige ting er således forskellige fra kultur til kultur og fra religion til religion. Den samme ting kan være hellig i en kultur og ikke-hellig i andre kulturer. Ting, som hos nogle er meget hellige og forbundet med stor værdighed og respekt, betragtes måske af andre som værdiløse, uden betydning eller ligefrem skadelige. Der er ingen overordnede faste regler at gå efter. Man må i hvert tilfælde skaffe sig relevante oplysninger for at vide, om pågældende genstand er gjort hellig.

Ting er hellige, når de bliver tillagt hellighed af en flok mennesker, som opbygger og omgiver tingen med særlige kulturelle værdier. Måske er helligheden tilstede, fordi deres Gud har velsignet tingen. Tilbedelsen er en del af helligheden. Heri indgår særlige regler for håndtering af den hellige ting.

I nogle tilfælde tillægges ting på grund af misforståelser en hellighed, som de ikke har. Et godt eksempel er de grønlandske tupilaq-figurer, som mange, ja selv nogle nutids grønlændere opfatter som hellige ting. Men det er ikke tilfældet. Tupilaq-figurerne har aldrig været brugt religiøst i grønlændernes religions- 


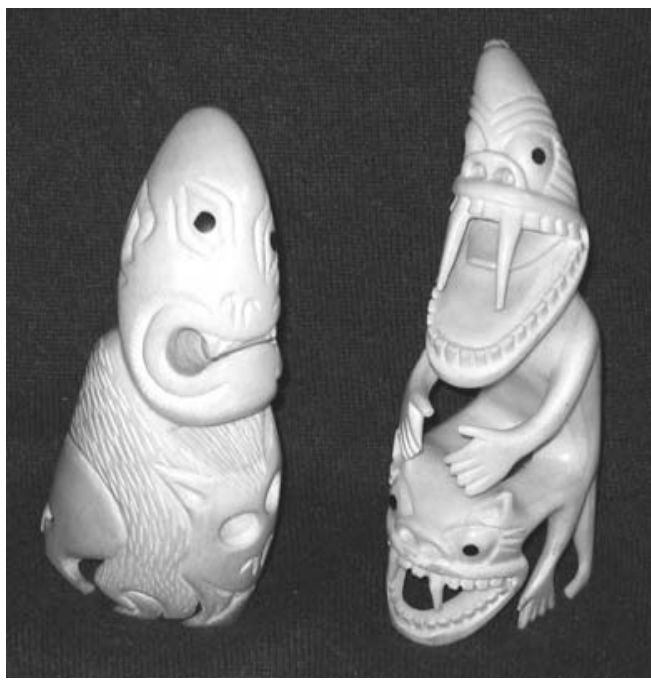

Gronlandske tupilaq-figurer $i$ tand fra Thule (tv) og Ostgronland (th). (Fot: R. Gilberg 2008).

udøvelse, men figurerne har været inspireret af religiøse forestillinger og fri fantasi. Tupilaqfigurer er turistsouvenirer, eller om man vil: kunst. Derimod er tupilaq-ånden en del af den grønlandske religion. Den er ikke en lille figur men en for almindelige mennesker usynlig dræberånd (Gilberg 2001).

\section{ER HELLIGHED NOGET SOM KAN BEVARES PÅ MUSEUM?}

Kan en tings hellighed overhovedet bevares udenfor tingens religiøse sammenhæng? Ofte vil en ting miste sin tilknytning til det religiøse liv, når den anbringes på museum. Men bliver den ureligiøs, eller mister tingen sin hellighed af den grund? Det mener jeg ikke, at tingen nødvendigvis gør. Dog kan det nemt ske, på grund af personalets uvidenhed eller ligegyldighed, at tingen ikke mere behandles med den respekt, som den ville få i sin oprindelige religiøse sammenhæng. Det kan være meget uheldigt, fordi man på den måde kan fornærme de mennesker, for hvem tingen er hellig., eller fornærme de krafter, som tingen repræsenterer. Har ting en hellig kvalitet, der er så stærk, at den kan bevares, når den indgår i en museumsamling eller udstilles i en udstilling?

Den hellighed, der oprindeligt er lagt i ting, kan bevares på et museum, hvis man vil det. Det kræver viden, vilje og respekt. Hellige ting befinder sig i en aktiv tilstand, mens de deltager $i$ et ritual eller i en dvaletilstand, mens de venter på næste ceremoni. Selv i denne dvaletilstand vil brugerne vise tingen den respekt, den har krav på. Det kan også ske på et museum. I de fleste tilfælde kan museumspersonalet varetage de tiltag, der er nødvendige. I andre må en særlig religiøs specialist fra netop den pågældende kultur indkaldes for at udføre en passende ceremoni.

Her er et par eksempler for at lette forståelsen og vise, at har man viden og ønsket, kan man vise respekt til glæde for:

(1) den pågældende kulturs bærere.

(2) for publikum, som derved fornemmer respekten.

(3) for sig selv, så ens samvittighed ikke lider under det.

(A) De nordamerikanske prærieindianere viser respekt for en hellig pibe ved at adskille pibehoved og pibeskaft, når den ikke er i brug, og lægger hver del hver for sig ved siden af hinanden i en slags hviletilstand. Denne måde at respektere den hellige pibe på kan sagtens udføres på et museum, både i en udstilling og på magasin. Det kræver blot, at man er vidende om det, og at man ønsker at respektere andres religiøse genstande.

(B) En lamaistisk, eller rettere en tibetansk, buddhistisk gude-figur er ofte af bronze og hul. Den indvies til religiøs brug ved at blive fyldt 
med bønner og andre symboler på noget helligt. Disse ting er med til at gøre figuren hellig. Det er utroligt uhøfligt og respektløst at åbne figuren og tage indmaden ud eller blot at rode rundt med det. Det er lagt ind for at være en del af den hellighed, genstanden har fået tildelt. Man skæmmer helligheden ved at lukke op. Ønsker man at have en buddhistisk figur, må man respektere, at den er som den er. Er figuren tom, er den ikke blevet indviet til hellig brug. I så fald er man mere frit stillet. Dog kan en hellig figur ved uvidenhed eller uheld, miste sin indre hellighed, og bør da alligevel behandles med respekt.

(C) I den buddhistiske verden, både i templer og i private hjem, er det meget respektløst at sætte en gude-figur på gulvet. Den skal helst stå i bordhøjde eller øjenhøjde. Det er måske ikke altid muligt, men gulvet kan man sagtens undgå. Det er meget uhøfligt at træde hen over en gude-figur. Under opbygning af en udstilling, kan det ske at en gude-figur midlertidig placeres så lavt, at man må skræve over den. Det vil være et udtryk for respektløshed, hvis man gør det. Med blot lidt omtanke kan det undgås at skæmme figuren.

Man bør heller ikke blande gude-figurer og figurer af almindelige mennesker. Hvis det er muligt bør gude-figurerne stå højere end menneske-figurerne, men det kan være vanskeligt i et lille magasin eller udstilling at få plads. Men med omtanke kan man nemt vise disse religiøse genstande den respekt, de bør have.

(D) En thangka - et tibetansk religiøst maleriskal rulles korrekt op nedefra omkring den kraftige pind, som med sin vægt får billedet til at hænge korrekt og udstrakt. Ved en sådan sammenrulning skjules hovedet af center-figuren på billedet til sidst, og på denne måde viser man Guden på maleriet sin respekt. $\mathrm{Nu} \mathrm{om}$ stunder laves mange thangka'er til salg til turis-

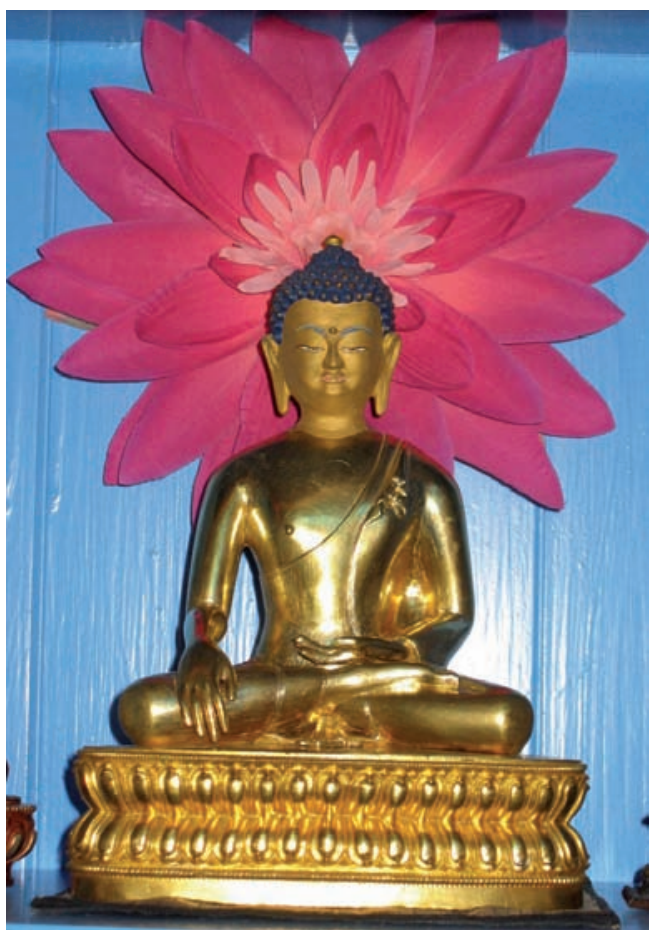

Forgyldt Buddhafigur, lavet i Sikkim 1978. (Fot. R. Gilberg 2008).

ter. Disse turist-udgaver har selvfølgelig de samme motiver, men de er ikke indviede og har ikke fået tillagt hellighed. Jeg synes dog alligevel, at man også skal vise disse en passende respekt, skulle de blive en del af en museumsamling. Blandt andet fordi det kan være svært at se, om en thangka er indviet eller ej. Visse museer opbevarer deres thangka'er helt flat, uden at være rullet, af hensyn til bevarelse af malingen på billedet. Det er selvfølgelig en god ting for bevarelse af maleriet, men selv her bør man huske på at håndtere en religiøs ting, så man viser den respekt.

\section{Send det Altsammen tilbage}

For mange år siden dukkede en ung sioux-indianer, George Horsecapture, op på National- 


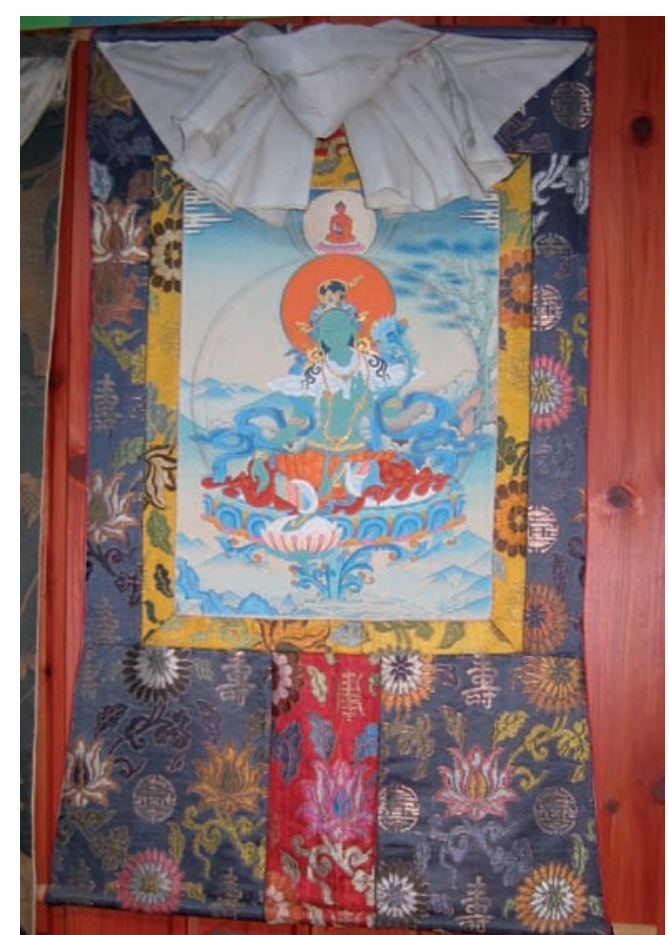

Tangkha, tibetansk tempelmaleri visende Den Gronne Tara. (Fot. R. Gilberg 2008).

museet i København. Han ønskede at se alle indianersager. Det fik han lov til at se og blev imponeret og overrasket over at opleve så fin en samling, der befinder sig i Etnografisk Samling, hvor mange indianerting ankom $\mathrm{i}$ midten af 1800-tallet. På et tidspunkt gav han på en høflig, men bestemt måde udtryk for, at alt, hvad indianere havde lavet, skulle leveres tilbage til dem. Selv nutidig turistkunst. Med hensyn til det sidste var jeg forbløffet. Men han var konsekvent i sin holdning: Alt! Så var det tid til en kaffepause, mente jeg. Min holdning er, at museer skal dele deres viden med oprindelsesfolket, så det kan vide, hvor i verden deres kultur befinder sig. Det vil være til fordel for begge parter.

"Hvis nu indianerne fik alle indianske ting tilbage fra alle Europæiske museer," forsøgte jeg, idet jeg prøvede at gå ind på hans tankegang, mens vi sad med kaffen, "så ville man i Europa ikke kunne fortælle om indianere. Uden viden om indianere, ville folk i Europa ikke kunne lægge pres på regeringen i USA, for at hjælpe indianerne, hvis de blev dårligt behandlet."

Horsecapture tænkte sig om og skiftede mening, måske skulle ikke alt sendes tilbage. Senere i livet blev Horsecapture museumsinspektør ved Buffalo Bill Historic Center i byen Cody, Wyoming, USA, som har en imponerende samling af Buffalo Bill sager, Western malerier, winchestere (geværer) og prærieindianer sager. Blandt andet en 50-100 helligbundter. Et helligbundt er en magisk pakke, som rummer en særlig kraft. Man valgte at anbringe disse helligbundter i aflåst rum, som først blev renset for urenheder, fysiske som åndelige, med en ceremoni. Der er nu kun adgang for medicinmænd og andre folk med respekt for de religiøse sager.

\section{LAKOTA MEDICINMANDEN LAME DEER AFHEL- LIGFICEREDE ET MEDICINBUNDT}

En Lakota-indiansk medicinmand, Lame Deer, kom på besøg i Danmarks Nationalmuseum i 1980 'erne. Han ønskede, som mange andre indianere, at se den indianske samling. Før han så "nærmere på ting i magasinet, gik han rundt med røgelse fra "sweetgrass" og viftede det omkring sig og tingene på hylderne, for at beskytte sig mod ting med farlige ånder i. Snart fornemmede han, at der var et helligt bundt og gik lige hen til det.

Et helligt bundt eller en medicinpakke (medicine bundle) er en pakke med noget $i$, brugt ved religiøse ceremonier blandt Nordamerikas indianere. Indholdet er ting, som har fået en åndelig værdi for den, der skaber bundtet. Et 
ROLF GILBERG

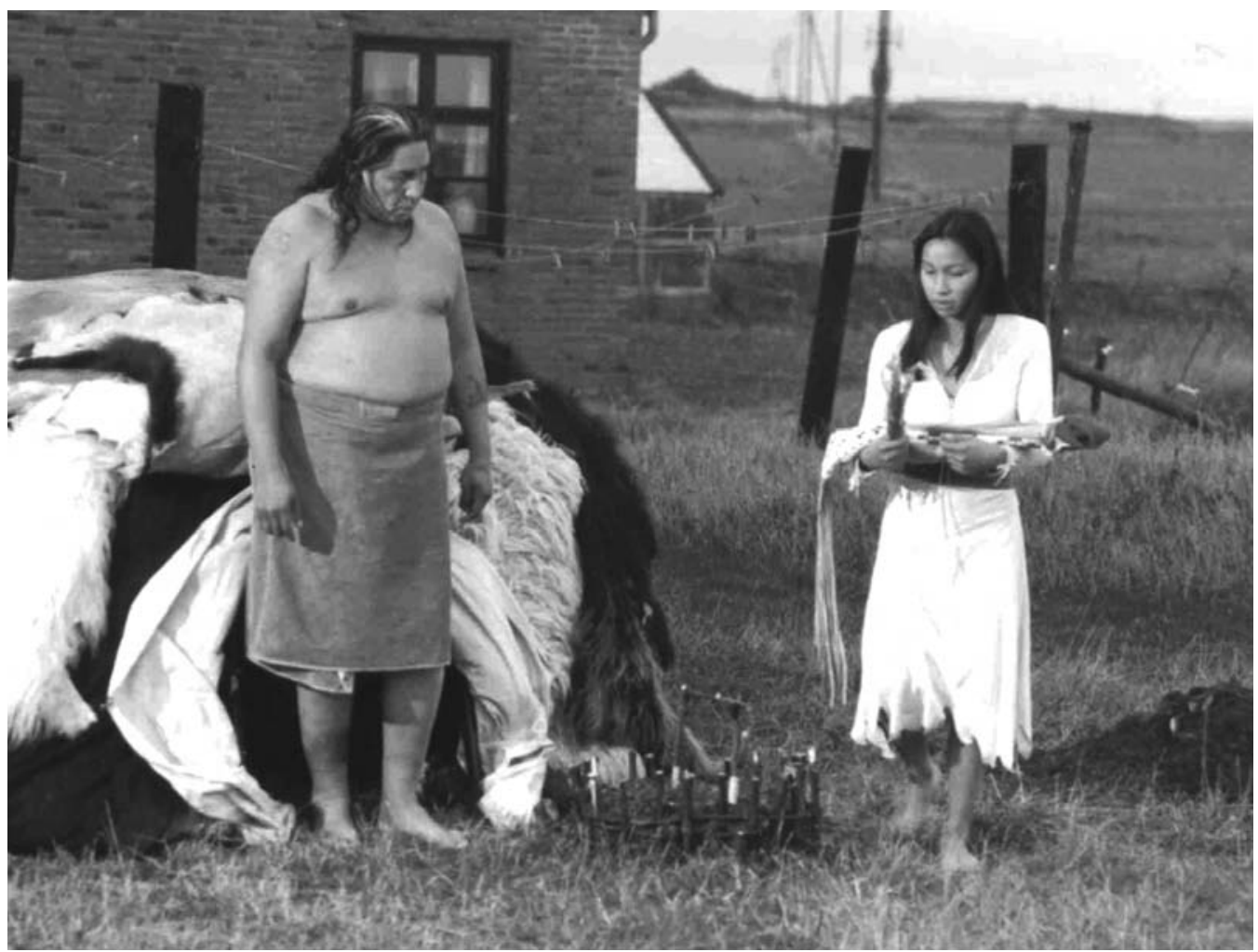

Lakota medicinmanden Lame Deer stär parat til at modtage det hellige bundt, bragt af en kvinden, den gronlandske skuespiller Elisabeth Heilmand, elev ved Tugaq-teateret i Fjeltring, Vestjylland. (Fot. R. Gilberg 1984).

helligt bundt er helligt for stammen, og det forventes at indholdet holdes hemmeligt. Det må ikke røre jorden, derfor indpakningen. Fremstillingen og åbning af et helligt bundt ledsages af bønner og ritualer. Kvinder håndterer meget sjældent et helligt bundt. Måske fordi mændene har gjort de religiøse ting til mandeting. Det hellige bundt kan nedarves i generationer.

Et helligt bundt betragtes som en meget kostbar ejendel, som symboliserer ejerens åndelige kraft, og kan indeholde styrke til at beskytte og helbrede. I takt med at ejeren bliver ældre, kan han tilføje ting i pakken. Normalt bliver bundtet begravet sammen med ejeren, men det kan også overdrages til en ven eller slægtning efter ejerens død

Lame Deer påpegede, at Nationalmuseet burde vedligeholde kraften. Han var opmærksom på, at museet ikke havde råd til at hente en passende medicinmand hvert andet år for at holde kraften ved lige. Han foreslog museet, at han i stedet for tog kraften ud af tingen. Han var interesseret $i$, at kraften (symbolet) vendte tilbage til det indianske folk, skallen (pakken/ bundtet) måtte museet godt beholde. Museet ejer pakken, men lakotaerne ejer den kraft, der 
var lagt i. Den ville han bringe tilbage til sit folk. Først ville han opsøge de ældste i sit folk og tale med dem om, den rigtige måde at gøre dette på.

Nogle år senere, i 1987, kom Lame Deer tilbage til Nationalmuseet for at udføre den rette ceremoni. Lame Deer ønskede at bruge denne lejlighed til at bevare sit folks religiøse ideer for sine efterkommere, derfor blev hele ceremonien filmet på video. Måske også for at han kunne vise andre museer, hvad man kan gøre.

Før den døgn lange ceremoni for at afhelligficere bundtet, åbnede Lame Deer og jeg pakken uden at andre var til stede. Lame Deer pakkede det hele sammen igen. Da hele ceremonien med at udtage helligheden var overstået, spurgte jeg Lame Deer, om det ville være mest korrekt at udstille "medicinpakken" åbnet eller uåbnet. Lame Deer svarede, at nu var den museets ting, som ikke mere var hellig, så museet kunne gøre, hvad det ville. Efter en kort pause tilføjede han, at han ville ikke åbne den, hvis det var ham, som skulle lave udstilling. Det råd har museet fulgt. Pakken har ikke været åbnet, siden Lame Deer lukkede den. Ingen vil alligevel kunne forstå pakken og dens indhold ved at se, hvad der er $\mathrm{i}$, fordi der ikke fulgte nogen forklaring med, da pakken i sin tid blev en del af museets samling. Det vil være naturligt at antage, at den eller de, som i sin tid har skabt netop dette hellige bundt, har haft en mening med de ting, der er $\mathrm{i}$, som hver har en symbolsk betydning, som tilsammen skaber den kraft, bundtet rummer, når dens kraft eksisterer.

I nyere tid, fortæller Dorthea Calverley på internettet, har man blandt indianerstammer i Alberta (Canada) ikke kunne finde unge mænd, som ville påtage sig ansvaret for de arvelige hellige bundter. Provinsmuseet overtog bundterne mod at love, at man i museet ville passe på dem på indianernes traditionelle måde. En stor ceremoni blev afholdt for at understrege ejerskiftet, og man optog alt på videobånd. Nogle af museets etnografer lærte sig de gamle ritualer og forsøgte at gennemføre de nødvendige ceremonier for at holde de hellige bundters kraft ved lige. Læseren vil måske spørge: Virker en ceremoni, hvis den bliver udført af en, der ikke er fra den kultur eller er del af den religion? Hvis vedkommende ikke tror eller viser respekt, vil det selvfølgelig ikke virke. Det kræver en seriøs uddannelse.

For kort tid siden på grund af den voksende kulturelle selvforståelse har en del indianere bedt myndighederne om at få deres hellige bundter tilbage. Det ser ud til, at unge mænd nu er parate til at lære ceremonierne, før de gamle shamaner dør. Det bliver interessant at se om det sker, slutter Calverley.

\section{Museet ENDREDE UdSTILLING EFTER KLA- GER FRA INDIANERE}

En dag dukkede nogle indianere op på museet i Philadelphia, fortalte museumsinspektør James Swauger (1974). De var utilfredse med kun at blive omtalt med 2 opstillinger, som var revet ud af sammenhængen og fremstod som eksotisk og barbarisk. Swauger gav dem ret og bad dem hjælpe med at lave en bedre udstilling. De gik så til deres bagland, før de fremlagde et forslag. Indianernes udkast og museets udkast blev forelagt en fælles valgt uvildig person, som var uden for begge gruppers indflydelse. Man ændrede ikke opstillingerne, men lavede nye tekster, som satte udstillingen ind i den rette sammenhæng og som gav en bedre baggrund for at forstå indianernes synspunkter.

Med dette samarbejde blev det tydeligt, at 


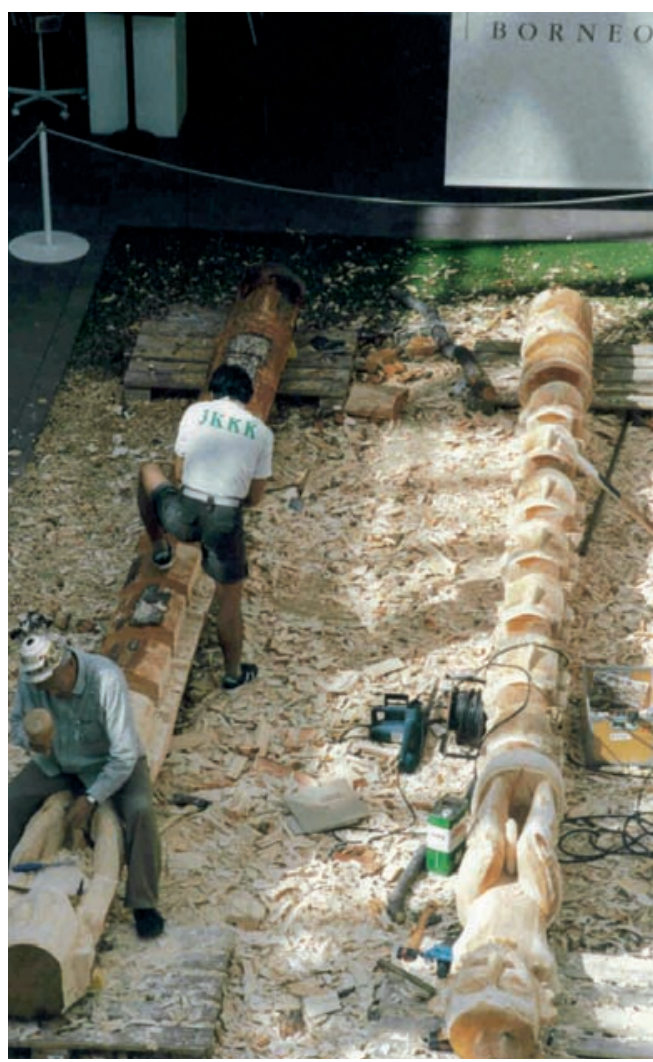

To lokale kunstnere fra Borneo udhugger totempale $i$ Nationalmuseets forhal 1993. (Fot. R. Gilberg 1993).

der kan være et problem med at finde de rigtige repræsentanter for de oprindelige folk. Hvilke fraktioner blandt de oprindelige folk, der skal bestemme, hvis der er konflikt.

\section{EN TOTEMPÆL}

En totempæl er en udskåret træstamme, hvormed nord-vestkyst-indianerne markerer vigtige begivenheder i familiens liv. Totempælen bærer familien og stammens symboler. Pælen bliver rejst udendørs i naturen, hvor den bliver stående, så længe den kan. Ofte er totempælens symboler af samme vigtighed som religiøse symboler.

Kan man lade en totempæl blive bevaret i et museum, eller vil det være mere rigtigt at sende den tilbage, hvor den kan gå til grunde $\mathrm{i}$ naturen? Hvorfor skal tingene bevares?

Man bevarer kulturelle ting for fremtidens mennesker - både for de oprindelige indfødtes efterkommere, her indianere, og for vore efterkommere, i dette tilfælde danskere, eller andre folk - så de kan få mulighed for at opleve og forstå fortiden, deres fortid, for derigennem at forstå sig selv og fungere som bedre mennesker i fremtiden.

En dansker købte en gammel totempæl hos nordvestkystens indianerne. Den kom på museum, fordi det er dér, man gemmer den slags, når de ikke længere opholder sig de naturlige steder. I museet beskyttes totempælen mod vind og vejr og mod insektangreb og folk som Killroy. Eftertiden vil kunne se den. Men var det hensigten med den?

Har vi lov til at tage den ud af den sammenhæng, den var del af? Den blev lavet til at være en "husker", et mindesmærke, et lokalt sted og kan overleve ligeså længe, som folk husker, hvorfor den står der. Så går den til. Tilstandene ændres. Man laver nye totempæle. Sådan går det, så længe samfundet fungerer på egne præmisser. Tiden går. Folket bliver en minoritet, storsamfundet breder sig. Værdier ændres. Nutiden får måske ikke brug for totempælen, men det har fremtiden, med mindre lokalsamfundet (indianerne) holder op med at være samfund og bliver opslugt. Vil man det? Skal man lave 2 totempæle. En til at stå i skoven, en til at stå i museet. Skal de være helt ens? Skal begge være indviede? Af hensyn til lokalsamfundets identitet, synes jeg, at totempælen skal være en del af hverdagen, og dermed blive 


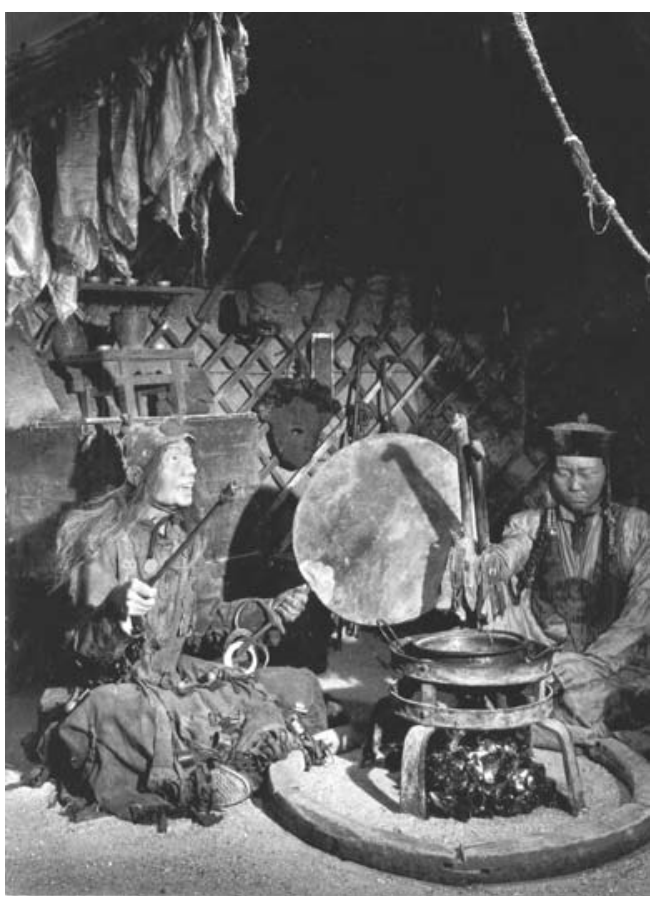

Museumsopstilling af et mongolsk shamantelt i Etnografisk Samling indtil 1988. Den kvindelige shaman sidder med sin tromme foran alteret. Hendes hjalperinde rakker shamanen et par hestestanger, som er shamanens andelige ridedyr til andernes verden. (Foto: Lennart Larsen 1975).

stående. Men jeg synes også, at nogle totempæle skal bevares langt ind i fremtiden for at give fremtidens mennesker balast i deres rødder.

Danmarks nationalmuseum har sine egne totempæle stående i forhallen, hvor de med deres beskytterånder sikrer livets gang i museet. Det er rigtigt, at de står netop i dette museum, fordi de er skabt til netop det formål. De blev udhugget og skabt i museets forhal, og en beskytterånd blev ved en ceremoni tilkaldt fra kunstnerens hjemland (Borneo) og anbragt i pælen.
Ideen med at lave 2 ens totempæle er slet ikke så dårlig. Den ene skulle opstilles i naturen, som traditionen er. Den anden skulle anbringes $\mathrm{i}$ et museum for at blive bevaret for eftertiden. Begge totempæle kan betragtes som "originalen", men med hvert sit formål.

\section{UKYNDIG KAN FREMKALDE FREMMEDE KRAFTER}

Når man arbejder i et museum med genstande fra kulturer fra "Langtbortistan", har man nu og da brug for at finde et sted, hvor bystøjen udefra ikke griber forstyrrende ind. Som ansvarlig for Centralasiens steppekulturer havde jeg nogle gange brug for at opleve det uendelige græslands voldsomme stilhed, især før jeg selv stod på stepperne. Men med storbyen Københavns konstante støj var det ikke muligt. Og dog - tilfældigt - eller var det det? - skulle jeg en dag hente en ting anbragt $i$ et mongolsk filttelt, der var udstillet i et rundt rum med et stort vindue, hvorigennem publikum kunne se teltet. Man kunne ikke gå direkte

Opstilling af et mongolsk lamaistisk tempel i Nationalmuseets udstilling "Buddhas Veje" 1970. Munkenes ansigter er kopier af rigtige mennesker. (Foto: Lennart Larsen 1970).

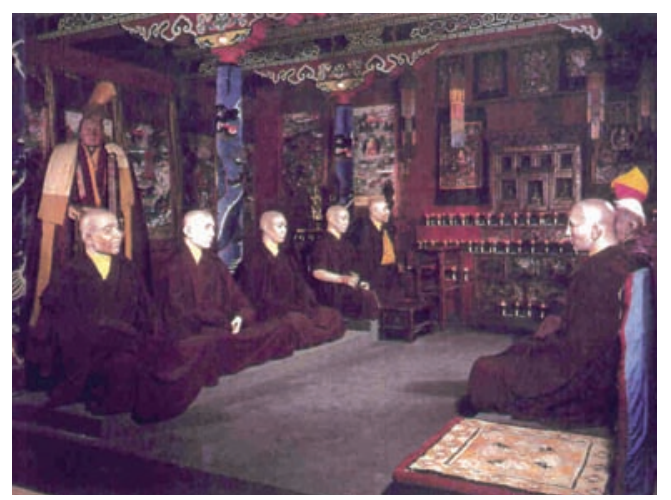


ind i rummet, kun ad en bagdør. Da jeg var nået ind $\mathrm{i}$ teltet og havde fået fat $\mathrm{i}$ tingen (hvad det var, har jeg glemt i dag), gik det op for mig, at jeg intet kunne høre af byens støj. Jeg satte mig og oplevede et lydløst vakuum på grund af museets tykke mure.

For ikke at skræmme nogen, som måtte komme forbi og kikke ind i teltet, havde jeg lukket teltdøren, som vendte ud mod en kæmpe tyk glasrude. Da jeg opdagede, at jeg intet kunne høre af byens larm, faldt jeg til ro og forestillede mig ryttere ride forbi udenfor måske en flok af Chinggis Khans krigere. Kun fantasien satte grænser. Jeg følte, jeg virkelig sad i et filttelt på den mongolske endeløse steppe. Jeg kunne blot åbne døren og se ud i museet, for at vende tilbage til virkeligheden, men det gjorde jeg ikke. Modstræbende vendte jeg senere tilbage til kontoret og byens larm.

På et af disse besøg i “teltet på steppen” pillede jeg ved nogle af de religiøse genstande, der var udstillet på det lille alter i teltet. Det var spændende at håndtere disse sager, og jeg lærte at bruge nogle af dem, blandt andet en dobbelt tromme. En tid gik det godt, for jeg havde valgt et tidspunkt, hvor der ikke kom publikum i udstillingen. Min overraskelse var alligevel stor, da jeg pludselig hørte stemmer udenfor. Straks blev jeg stille og tavs. Kort efter genkendte jeg en af stemmerne. Det var en af mine kollegaer. Den anden stemme tilhørte et barn. Jeg turde ikke åbne døren og se efter, for ikke at skræmme dem, eller for at de skulle opdage mig inde i montren. Nå, jeg tog det med ro. Denne kollega tog nu og da sit barn med i museet. Det var naturligt, at han ville vise barnet noget, som var uden for hans arbejdsområde, mens udstillingen var lukket for publikum. Da der havde været stille længe nok, skyndte jeg mig tilbage til kontoret. Senere på dagen mødte jeg kollegaen. Jeg lod en bemærkning falde, om det opbyggelige ved at vise sit barn både sin arbejdsplads, og hvordan fremmede folk lever. Han så overrasket på mig og fortalte, at hans barn havde ikke været der den dag, og spurgte: "Hvad har du været i gang med?" Jeg fortalte ham det, og han advarede mig om at være mere forsigtig med, hvad jeg gik og legede med. Det kunne starte ukontrollerede begivenheder, fordi et museum er fyldt med kraftfulde åndelige kræfter.

\section{HARMLØS UDEN H/ENGELÅS}

Nogle religiøse genstande kan være hjemsted for ånder. I sig selv behøver ånder ikke at være skadelige. De er ofte ligeglade med menneskene, men bliver de provokeret, kan de svare igen med ulykker og andet besvær. Det er en af grundene, man skal omgås ukendte religiøse ting med omtanke. Dog i visse tilfælde ved museumsmanden, at en bestemt religiøs ting er ufarlig.

I 1936 sad den danske mongolist Henning Haslund-Christensen ved dødslejet af en mongolsk shaman, Dølgøre, i det nordøstlige Indre Mongoli. Mens de ventede på døden, talte de om dagligdagen og om Dølgøres shamandragt, som lå ved siden af. Haslund-Christensen undrede sig over et par russiske hængelåse, som var syet på dragten. Forklaringen var, at da Dølgøres far mærkede han skulle dø, og sønnen endnu ikke var parat til at træde frem som shaman, manede han alle de ånder han kontrollerede, ind i de 2 hængelåse, gav nøglen til en god ven, og sagde, at når Dølgøre var blevet shaman, kunne de låse op for dem igen.

På sit dødsleje havde Dølgøre selv et problem. Han havde ingen arvtager, som kunne overtage kontrollen med ånderne. HaslundChristensen tilbød at tage dragten og de deriboende ånder med til Denmark, men det ville 
Dølgøre ikke høre af. Nok havde han problemer, men han ville ikke udsætte danskerne for en flok ukontrollerede ånder. I fællesskab fik de ideen om igen at bruge hængelåsene. Således fik Haslund-Christensen en total harmløs shamandragt med til Danmark. Det gjaldt dog ikke de andre shamandragter, han hjembragte. Så dem bør man omgås med forsigtighed og respekt.

\section{HÃNDTERING AF ÅNDELIGE SPECIALISTER I MUSEET}

Det sker at åndelige specialister - præster, åndemanere, medicinmænd, synske og den slags - besøger et museum. Ofte går de selv rundt og ser på tingene, men det sker at sådanne personer ønsker at komme bag glasset og på magasinerne. Det får museumsmedarbejderen ud af sine gemmer.

En gang fik museet besøg af en hvid mand, der i Sydamerika havde uddannet sig til shaman. Han ville naturligvis gerne se de udstillinger, der havde med shamaner at gøre i museet. Da vi nærmede os en stor montre med et halvt filttelt, hvor i der befandt sig 2-3 mongolske shaman-figurer klædt i originale dragter, stoppede han op og sagde, at han kunne føle vibrationer eller en udstråling. Han spurgte mig, om jeg kunne, men jeg er ikke udstyret med nogen særlig god antenne, så jeg modtog ikke noget signal. Jeg har lært, at fordi jeg intet opfatter, betyder det ikke nødvendigvis, at der intet er. Da vi endelig stod foran shamanmontren, ønskede gæsten, at vi holdte i hånd og dannende en cirkel. Igen blev jeg spurgt, om jeg nu kunne føle energien løbe gennem vore arme. Som sagt er min antenne dårlig, så det kunne jeg ikke. Det forhindrede dog ikke, at jeg kunne forstå, at andre kunne føle det, og så måtte det jo være der - for dem. Her er det også vigtigt at vise respekt. Igen betyder det ikke, at man skal lave om på sig selv. Man skal til gengæld heller ikke lave om på andre. Vi gik derfra med hver sig oplevelse.

\section{KUN FOR INDVIEDE}

Et lokalt museum i Edmonton (Alberta, Canada) for Nordamerikas indianere, Blackfoot, har valgt at samle alle hellige ting $\mathrm{i}$ et særlig rum, hvor kun indviede har adgang. I rummet har man samlet ting, som på grund af deres hellighed ikke må ses af hvem som helst. Kun folk, som i det virkelige liv har lov at se disse ting, må komme ind i dette særlige rum. På den måde har man valgt at vise sin religion respekt. Selvfølgelig er det kedeligt for os andre dødelige, men det er vigtigere at vise sin religion respekt end at nogle fremmede beglor folkets helligeheder. Det må vi andre respektere.

I området omkring de store søer i Nordamerika brugte indianerne, især irokeserne, nogle religiøse masker, som generelt blev kaldt "False Face". Indianerne har bedt museer, som har den slags masker, om ikke at udstille dem, så almindelige mennesker kan se på dem. Her kommer museumsmedarbejderen i et dilemma. På den ene side er trangen til at fortælle om andre kulturer til mindste detalje, og på den anden ønsket om at vise pågældende folk en passende respekt. Personligt mener jeg, at man ved særlige hellige ting bør følge folkets ønske, eller i det mindste lave udstillingen i samarbejde med pågældende folk. Jeg mener, at man sagtens kan respektere andres religion, selv om den er anderledes end ens egen. At vise respekt betyder ikke, at man selv går ind for den. Respekten er der for at vise, at menneskene er mangfoldige i deres opfattelser af livet og verden omkring dem. 
ROLF GILBERG

DET MAN IKKE SER, HAR MAN IKKE ONDT AF - ELLER HAR MAN?

I 1992 arbejdede jeg på en udstilling om mongolernes kultur, hvor der blandt andet blev vist et hjørne af et lamaistisk tempel i tibetansk stil. Røde søjler holdt loftet oppe og imellem dem sad 2 rækker munke (giner). Da jeg stod og arrangerede gude-figurerne på alteret, og måtte vende mig om efter flere figurer, fik jeg et chok. Maleren havde kun malet alle de sider, der kunne ses, når man stod uden for montren. Hele illusionen var totalt væk for mig. Jeg fandt maleren og forklarede, at jeg kunne ikke skabe en tempelhal, når kun den ene side var malet. Han forstod og malede resten. Det gav en mere rigtig stemning, og dermed en større respekt for de mange religiøse genstande, templet blev pakket med.

I offerskålene på alteret burde man fylde vand om morgenen og tømme dem om aftenen. Men i en museumsudstilling er der hverken mandskab eller tid til at gøre den slags. Men det er der tænkt på, for munke forlader deres alter i længere tid. Så fylder man sine offerskåle med ukogt ris eller andre offergaver, som ikke fordamper eller forsvinder på anden måde. På den måde kan man stadig med en lille indsats vise passende respekt for de udstillede genstande og tankerne bag dem. Det er også i orden at bruge kunstige blomster. Det er altsammen med til at give den rigtige stemning, og dermed få publikum til at vise respekt for, hvad de ser på. Det er ikke hensigten at omvende publikum til en anden tro, kun at få dem til at forstå og vise respekt.

Håndtering af hellige ting gælder ikke kun genstande, men også omtale af dem. En besøgende ville gerne vise sin interesse og spurgte engang: "Jeg husker ikke helt om det er 97 eller 99 Buddhaer, der findes?" Selv om det umid- delbar lyder som et dumt spørgsmål, må man ikke gøre grin med det, hverken for Buddhas eller gæstens skyld. Jeg ved ikke selv, hvor mange Buddhaer der findes, har været eller vil komme. Jeg ved til gengæld, at alle kan blive Buddha, hvis de arbejder for sagen. Så teoretisk kan der være lige så mange Buddhaer, som der er mennesker. Gæsten fandt selv ud af, at det ikke var et relevant spørgsmål at fremsætte.

\section{MAN SER PÅ ANDRE MED SIN EGEN} KULTUR

Den visuelle opstilling i en udstilling har stor indflydelse på, hvordan beskueren opfanger og opfatter det udstilledes hellighed. Jo bedre og mere forstålig man kan forklare fremmede kulturers traditioner, jo bedre kan publikum forstå og få grundlag for at vise den respekt for andre, som vil være med til at bevare fred mennesker imellem. Af respekt vil der være genstande, som man ikke vil udstille, fordi sådanne kræver en særlig grundig forklaring. Det betyder ikke, at man aldrig må vise sådanne ting. Man skal blot gøre det med omtanke og tilstedeværelse af en kyndig person, som kan vejlede beskueren.

Ofte betragter publikum de udstillede genstande med en forståelse, der bygger på deres egen kultur. Anderledes kan det ikke være. Her må museets personale så være med til at bringe den rigtige forståelse ind i billedet, enten med tekster, lyd eller samtale. Samtaleformen er den bedste, men også mest resurse krævende. Ved at tale sammen kan man straks se og høre, om budskabet er gået rigtigt igennem, og er det ikke, kan man straks give mere viden, så modtageren ender med at forstå. Dog er der kun tale om at forstå, ikke at missionere og ændre gæstens meninger. Det må gæsten selv slås med. 


\section{RESPEKT OG OMTANKE}

Museumsfolk vil ikke kun få det godt med sig selv, men også med sine gæster, hvis disse opdager, at personalet viser respekt for netop gæstens kultur. Der skal ikke den store indsats til, for at håndtere gude-figurer og andre religiøse ting på en pæn måde. Der skal ikke den store indsats til, for at undlade at gøre grin med eller nedgøre andres kultur. Artiklen kommer med nogle eksempler for at vise problemstillingen. Der er selvfølgelig mange andre ting, som kunne være nævnt, og som museumspersonalet opdager i dets kontakt med repræsentanter for andre kulturer. Det er ikke hensigten her at bringe en fuldstændig liste over, hvad man skal og må. Hensigten er mere at få læseren til at reflektere over de givne eksempler og finde andre selv. Jeg foreslår en ændret grundholdning frem for en forbudsliste, som aldrig vil blive komplet alligevel.

Kort og godt kan håndtering af hellige ting beskrives med to ord: Respekt og omtanke. Ved selv at respektere de hellige ting i museet, uanset om de tilhører ens egen kultur eller en fremmed, vil det smitte af på publikum, og vil formå at få det til at forstå og vise hensyn. Man skal ikke latterliggøre eller fordømme andres tro, eller omtale den som hedensk eller overtro. Man skal slet ikke synke ned på visse avisers niveau, som kun er ude på at provokere med diverse tegninger.

\section{REFERENCER}

Alpers, Svetlana [1991]: The Museums a Way of Seing. Exhibiting Cultures: The Poetics and Politics of Museum Display, redaktion: Ivan Karp \& Steven D. Lavine (Washington DC: Smithsonian Press).

Calverley, Dorthea [1989]: The Medicine Bundle.
www.calverley.ca/Part01FirstNations/01104.html

Gilberg, Rolf [1997]: Hvem ejer museumstingene? Nordisk Museologi, 1997(1):117-131 (Umeå). Gilberg, Rolf [2001]: Tupilakken - den usynlige dræber og turistfiguren. Tidsskriftet Grønland, 48(2): 67-79 (København: Det Grønlandske Selskab). Swauger, James L. [1974]: Indianerne åbnede vore øjne. Jordens Folk, 9(4):166-169 (København: Dansk Etnografisk Forening).

* Rolf Gilberg er magister (mag.scient.) (1971) og ph.d. (1996) i etnografi ved Københavns Universitet. Har 1971-2006 veret ansat som museumsinspektor ved Etnografisk Samling $i$ Danmarks Nationalmuseum. Har skrevet ca. 300 bøger og artikler om isar eskimoer, mongoler og shamaner, samt om museologi.

Adresse: Stokholmsvej 43, DK-3060 Espergarde, Danmark.

E-mail: ilbe@os.dk 